DOI https://doi.org/10.30525/978-9934-26-065-0-15

\author{
Galyna Sklyarenko, \\ PhD. Art History, Senior Research Fellow, \\ Senior researcher at the Department of Fine and Decorative Arts \\ of the Institute of Art History, Folklore \\ and Ethnology named after M. Rylsky NASU, \\ Department of Visual Practices \\ of the Institute of Contemporary Art NAAU, \\ Kyiv, Ukraine \\ https://orcid.org/0000-0001-5878-6147
}

\title{
“NEOBAROQUE” IN UKRAINIAN ART IN 1980S-2000S: ANALYSIS OF NATIONAL EXPERIENCE
}

The article analyzes the peculiarities of the interpretation of Baroque traditions in the art of the late 1980s-2000s years. In the works of artists the Baroque appeared not only as one of the main traditions of Ukrainian art, but also as a cross-cutting problem of national culture, which requires discussion and study. Exploring in a figurative way the contradictions of national experience, the new artists drew attention to the issues of national history, to contradictions of socio-political progress and cultural development of the country.

Keywords: Baroque as a model of culture, art, traditions, analysis and critique of artistic experience.

Among the issues of the new era of Ukrainian art, which began with the years of perestroika, a significant place belongs to the revision and analysis of the national artistic experience, the search for relevant content and directions. Moreover, contemporary art itself appears as a realm of ideological and aesthetic discussions, critique of culture, rethinking traditional models of artistic expression. Since the perestroika, which became a deep historical turn of the epochs, culminating in the collapse of the USSR and the establishment of Ukrainian state independence, the analysis of the dimensions of Ukrainian cultural space acquires new meaning, 
Galyna Sklyarenko. "Neobaroque" in Ukrainian art in 1980s-2000s: analysis of national experience

sharpens attention to national and regional contexts. It is no coincidence that, as critics wrote, for artists from the former USSR the most important task is the "determining their relationship with the heritage behind them (...), not so much to design their future as to design their past" [2, 24]. Moreover, in Ukraine the consequences of colonialism, which led to the lack of a critical view on historical experience and unstructured traditions, were added to the general post-Soviet problem with its need to make up for the long-term separation from the world artistic processes, to return names and works erased from the cultural space by the Soviet system. After all, the century of statelessness, the rupture of Ukrainian lands between other cultures complicated or even made national progress impossible, hindered critical understanding of reality, generating in the public consciousness a mythological perception of heritage, which in the empires of late 19th- early 20th centuries and especially in the USSR was subjected to constant political selection. Therefore, one of the cross-cutting problems of Ukrainian culture during the 20th century (this task is still relevant today) remained self-awareness and selfdetermination based on historical experience and the latest challenges of the time.

Moreover, the modern artistic progress is not possible without a constant reassessment of ideological and aesthetic values. In this regard, the concept of "inventing traditions" by British culturologists in the 1980s, which was widely involved in the humanitarian studies, offered a new perspective on the vision of the traditions: not only as a natural "set of ideas, rites and customs of practical and social activities passed down from generation to generation, and act as one of the regulators of social relations", but also as a fully conscious "use of old material" for the new purposes. The experience of the 20th century has shown that the very appeal to the past has repeatedly appeared and continues to be one of the effective means of legitimizing ideological and political constructions, the basis of one or another collective unity. As E. Hobsbawm notes: “...even revolutionary movements support their innovations by appealing to the 'past of the people'; and a history, that has become part of the body of knowledge or ideology of a nation, state or movement, is not something that is actually preserved in popular memory", but what was selected, recorded, depicted, popularized and institutionalized by those who were in charge (...). All this is based on exercises in social engineering, which are often conscious and always innovative, at least because historical novelty presupposes innovation" [5, 27]. 
In this context, the appeal of the new generation to Baroque was quite natural, due to both the intentions of postmodernism, where the features of the Baroque revealed as a kind of crisis model of culture, in tune with the latest issues and the fundamental role played by Baroque in Ukrainian history.

As a world art style, Baroque was discovered in the modernism era. It was at the end of the 19th century in the studies of J. Burkgart, K. Gurlitt and G. Welflin $[3,87]$ where Baroque became an important turning point in culture and art, which initiated new aesthetic priorities, directions and methods. It was the Baroque that put forward the categories and concepts that defined the main features of modern art: "concept" - the idea, "model" as a mental structure, the category of "new", which since the 17th century become the most important in the works, and with it - non-canonicality, emotionality, subjectivity, expressiveness, which replaced the idealized beauty. Since the Baroque, spreads the influence on the art of scientific research, as well as geographical discoveries, which attracted to the assimilation of another, unusual life experience. At the same time, the Baroque era was also a time of religious wars, political confrontations, secularization of culture, spiritual crisis and the search for new controversial ways of mastering reality, the reaction to which was the irony and tragedy of the worldview. The Baroque proposed new dimensions of space and time, the new awareness of man in the vastly changing cosmos, gave rise to a special "post-catastrophic" worldview, the existential drama, which was in tune with the latest worldview, supported by modern social, political, industrial disasters. It is no coincidence that the Baroque is seen today as a special type of culture that is relevant in times of crisis, turning points, and reproduced in the media age, where its latest - virtual dimension is similar to those fascination with the infinity of space and a sense of the fragility of the foundations of the world order that inspired the Baroque. Baroque ups and downs, irony and drama, the tendency to theatricality and decorativeness are strongly intertwined in the modern "society of performance" (Guy Debord), "theater-cracy" (J. Balandier) with their PR technology and manipulation of public consciousness. Since the Baroque era, the relationship of art (and the artist) with society - the government, religious institutions, morals, customs and tastes of people is problematizes. Art is increasingly "undermining the foundations" of the established, generally accepted; but gradually it is the author's subjectivity and originality that form a new powerful tendency that is becoming the "norm" of the 20th century. 
Galyna Sklyarenko. "Neobaroque" in Ukrainian art in 1980s-2000s: analysis of national experience

In the middle of the 20th century E. d'Ors put forward the idea of "eternal Baroque", which expresses "the infinity of space, dynamism, the state of internal fracture", where Baroque is not only an artistic but above all a philosophical category, a certain worldview model that manifests itself at different stages of culture for understanding the incomprehensible [11]. Analyzing the Baroque culture, M. Conrad emphasized its programmatic transition: "We now live in an era of great antinomies and their collisions, - he wrote, - And we know that our time is also an epoch of great urgency. That is why we now understand Baroque even more clearly than before" [13, 265-267].

The theme of Baroque in postmodernism acquires a new meaning, outlining a powerful neo-Baroque trend in which the traditional dimensions of historical style have received a new version. Modern art has introduced something else the analytical and critical perception of cultural heritage and "specific attitude of the artists to cultural and artistic traditions" [23, 79-80], where "the new work (...), provocatively denying all previous art, still provides a horizon of tradition as a denied instance of understanding and (...) in this newly discovered horizon in a new way brings together with the present the art of the past, even often allows us to see them in a hitherto unrecognized meaning" [33, 285]. The appeal to the "ephemerality of the Baroque" (J. Lipovetsky), to its excessive aesthetics (M. Meffesoli), diversity and palimpsest (K. Bluesy-Glucksman), because of its "impurity" (Guy Scarletto) appeared in postmodernism as one of the possibilities of culture, which did not repel the others, built on a purely rational basis, but one that carried a multidimensional view of the world. The main category of postmodernism becomes J. Baudrillard's "simulacrum", "a copy that has no equivalent", and the understanding of the magic of art itself - "the ability to depict and assert the non-existent" (A. Badiou) acquire a special meaning in this context. New technologies have added their features to the "Baroque of our time", which not only turned virtuality into a clear sign of culture in its broadest sense, again, now in the globalized media world, recorded the relativity of true and fictional, real and artificial, existent and illusory.

In Ukrainian culture, the theme of the Baroque is one of the most important, fundamental and debatable. "Central epoch in the spiritual history of Ukraine" (D. Chizhevsky), Baroque outlined a broad tradition and retained its relevance, in a way echoing in the works of the 20th and, as is obvious, the 21st century. 
To a large extent, the Baroque itself determined almost the main archetypes of Ukrainian culture, influenced the worldview, aesthetic priorities, and initiated the images and mythologies that became decisive for it. As S. Krymskyi emphasized, Baroque in Ukraine "is historically connected with the spiritual formation of the Ukrainian nation, therefore, in a sense, performs ethnocreative functions, ie is a present component of the process of revision of the world experience by Ukrainians on their own ethnic basis..." [14, 23]. However, even here its experience is far from monosemantic. The Baroque era in Ukraine was a time not only of the rise of the national liberation movement, but also of religious wars, the struggle for independence and its loss, the "Cossack chivalry" and the era of Ruin, the tragedy of civil strife, the choice between "East and West" and a new division of Ukrainian lands between neighboring states. And although it was at the height of the Baroque era that Ukraine lost its independence, and later, due to the introduction of serfdom in the sub-Russian lands basically returned to feudalism, its values were preserved in its culture for a long time, creating stable national myths. The Baroque itself became a long-term embodiment of the national dream in Ukraine, fueling the visions of modern reformers.

It is worth quoting at least one of the authors of the "Ukrainian style" at the turn of the 19th-20th centuries, architect O. Dyachenko, who wrote: "If there was no Baroque - Ukrainians would have created it... Baroque is a Ukrainian element that has permeated not only architecture, furniture, ornament, clothing, carving, as well as song, music, literature. Baroque is a bright expression of the Ukrainian national face, Baroque and Ukrainian temperament are synonyms" [31, 315]. And the researcher of Baroque G. Pavlutsky emphasized: "In Ukraine they created their Baroque, took from the West all the components of its form, but reworked them in their own way; something new has emerged, such that was not seen in the West, something that is certainly peculiar, and often beautiful" [31,279].

The Baroque tradition, like the Baroque in Ukraine itself, is peculiar, often unlike European ones. Their content and role in culture are closely intertwined with historical conflicts, where the choice and then the loss of the European vector of development will become one of the main problems of national culture. Attracted to the Ukrainian space as a "modern trend" (D. Chizhevsky), after a longer than in Europe period of the Middle Ages, the Baroque became here a certain "catching up" of its time, on the other hand - an expression of national identity. 
Galyna Sklyarenko. "Neobaroque" in Ukrainian art in 1980s-2000s: analysis of national experience

A special "concentrated" model of national artistic development emerges from the Baroque, when at "one turn of history" in art there are present not only different directions, but also different stages, forcing the culture to simultaneously solve multi-stage issues. This will be especially noticeable in the 20th and 21st centuries.

Since the Baroque era, regionality has been sharpening in Ukraine, which will pass through the following centuries and become one of the tense problems of post-Soviet society. Baroque in Ukraine was manifested in several versions: Eastern and Central Ukrainian, Orthodox, "Cossack"; western, which spread to Ukrainian lands along with Catholicism; and next to it - the imperial-Russian, which fueled Rastrelli's architectural masterpieces, painting and literature. At the beginning of the 20th century, its researcher G. Lukomsky wrote about the "mix" in the Ukrainian Baroque of various components - Old Russian, Polish, German, Italian, and others. The complex multifaceted genesis of Ukrainian art will continue to manifest itself in various historical contexts.

The ideological mythologizing of history in Ukraine begins with the Baroque. Reconstruction of ancient Rus churches in the new - Baroque spirit will establish in the culture new samples of historical progress and aesthetic priorities. Later, the religious philosopher and researcher of the ancient Rus Middle Ages G. Fedotov will reproach: "Admiring the wide tricks of the Kyiv Baroque, how not to be annoyed when it stuck, like a layer of fat on slender, modest walls of princely temples? No matter how dear the memories of the national awakening of Ukraine-Little Russia are, they disappear before the memory of the only, great day of Kyiv's glory. In this glory everything disappears" [28, 216]. Thus, the Ukrainian Baroque finds itself in the circle of cultural and political issues, and the attitude to it will be connected with national priorities in one way or another. From the Baroque in Ukrainian culture are established images that will become symbols of national character and the idea of national spirit: Zaporozhian Sich, Cossack freemasonry. It gave impetus to the national myth of a lost Ukraine, buried mounds of former glory, which will be mourned for centuries to come as an unfulfilled fate. On this occasion, in 1918, M. Hrushevsky wrote: "There are dangerous elements in this folk romanticism, which should be watched out as matter too suitable for the breeding of any reaction bacterium (...)....Reactionary Cossack formats can still emerge under any other firm and stand in the way of 
our political development with great harm to it!" [9, 13-14]. Meanwhile, as the modern researcher emphasizes: "undergoing linguistic and cultural oppression, the Ukrainian intelligentsia has always been nourished by the memory of the culture of the Cossack era", where "the struggle of national-democratic and imperial-totalitarian structures in the common consciousness during the 19th and 20th centuries is based on the basis of the confrontation of Baroque and classicist consciousness" [19, 104].

The "discovery" of the Baroque in Ukraine, as well as in Europe, took place at the turn of the $19^{\text {th }}-20^{\text {th }}$ centuries. However, domestic modernism had its peculiarities, where its main and defining task, in contrast to Western Europe, was not only the democratization of culture, the assertion of the leading value of human individuality, but above all - the national self-determination, through which Ukraine, then fragmented and stateless, had to become an active subject of historical and cultural progress. Naturally, in the Ukrainian modernist paradigm, the "invention of traditions" of the Baroque became one of the fundamental elements of the national space. The appeal to the Baroque outlines the history of modern Ukrainian art, responding in its works at the level of plots and themes, historical stylizations and subjective authorial versions. The idea to analyze the Baroque tradition in Ukrainian art - from the 17th century until now was carried out 2012 in the research exhibition project "Myth "Ukrainian Baroque " at the National Art Museum in Kyiv (curators G. Sklyarenko, O. Barshinova), where, as its authors emphasized, Baroque was revealed not only as a powerful figurative and stylistic tendency, but also as a worldview-aesthetic model of culture, which concentrated in itself the crisis aspects of its development [12]. The exhibition offered a new look at the history of national art: not as a successive change of periods and epochs that either denied or imitated each other, but as a complex, full of controversy development of a pervasive, in this case Baroque model, which at each stage demonstrates different contexts and meanings. Moreover, the "ghost of Baroque" have repeatedly acted in Ukrainian art as a mean of re-actualizing the past and establishing its dialogue with the present.

It should be noted that a previous attempt to update the perception of the Baroque in Ukrainian art was proposed in the project "From Baroque to Baroque" in 1996 (author of the project Y. Lutskevich, NAMU). It consisted of a conference and an exhibition, where along with the works of the 17th and 18th centuries were 
Galyna Sklyarenko. "Neobaroque" in Ukrainian art in 1980s-2000s: analysis of national experience

presented the paintings by Y. Lutskevich, M. Storozhenko and architectural works by D. Yablonsky. His main idea was to consider "Baroque as a timeless type of cultural consciousness, which did not die with the last masters of ancient Baroque and continues to influence the creative pursuits of contemporary artists" [6, 3].

The exhibition "Myth "Ukrainian Baroque" broadened the view on the tradition, problematized its content and direction, attracting to a united space works of different eras. Having traced the historical periods - from the 17th century to the present, Baroque acts in Ukrainian art as a kind of figurative and semantic core, from which stretch multidirectional streams, which seem to be far apart, but in fact are closely related. Thus, in particular, the magnificent ornamentation of iconography and parsuna of the $17^{\text {th }}-18^{\text {th }}$ centuries is reflected in the ornaments of G. Sobachko and P. Vlasenko; Baroque theatricality and complex spaciousness are seen in the sculptures of O. Archipenko; "Legends" of the Ukrainian Baroque period will pass through the works of Taras Shevchenko; will inspire artists of the early 20th century - from G. Narbut and his school, which returned the images and aesthetics of the 17th and 18th centuries in a new culture, fueling the ideas of national revival, to modernist innovators O. Bogomazov, V. Meller, S. Rybak, A. Petritsky, O. Exter, whose authorial interpretations of European trends "melted under the hot breath of the Ukrainian Baroque" (V. Markade); acquire a new mythological content in the fictional plots of socialist-realist "historical" paintings by M. Samokish; later will nourish the Baroque stylizations of the already "unofficial artist" of the late Soviet era F. Humeniuk. In the second half of the 20th century the Baroque visions inspired the work of Y. Lutskevich, opening the space to the freedom that opposed the ideological canons of Soviet aesthetics; filled the congratulatory-dramatic painting of A. Limarev; its features are present in the dramatic sculptures by M. Hrytsiuk, where the classic content is combined with the complex spaciousness of sharpened compositions; Baroque style became the basis of S. Yakutovych's graphics... However, the importance of the Baroque is not limited to art and aesthetics, and is often filled with socio-political content: in the Baroque costumes in 1918 G. Narbut dressed the army of Hetman Pavlo Skoropadsky, his ornaments and symbols were decorated with karbovanets of the Ukrainian National Republic. It is no coincidence that during the Soviet era, the Ukrainian Baroque was branded as a "manifestation of bourgeois nationalism", many of its monuments were destroyed. However, declaratively rejecting its values 
as unacceptable, socialist realism in its own way used its basic features: active influence on the viewer, exaggerated pathos, theatricality, artificial exaltation. Examples are the Baroque-themed "thematic tapestries" of the 1930s, paintings by M. Khmelko, or projects of unrealized architectural ensembles of the late 1930s to 1950s that were to appear (and partially appeared) on the site of real Baroque buildings.

In this context the neo-Baroque "Ukrainian wave" was a natural stage in the development of national tradition, which at the new historical stage established a more complex relationship with tradition, appealing not only to its origins but also to further use in Ukrainian art. Eventually, for the artists of the beginning and second half of the $20^{\text {th }}$ century Baroque served primarily as a source of renewal of imagery and style and the establishment of the national tradition; the authors of the "new wave" of the mid-1980s-1990s, on the contrary, almost for the first time saw the Baroque as a problem of Ukrainian culture, which concentrated the paradoxes of national progress. The "object of interest" of Ukrainian artists was the very content of the national tradition with its constant revolving around the Baroque and the inability to reach another level of comprehension of reality. The ambiguity of the stereotypes that arose on its basis, the traditional domestic mythology of the worldview and the retrospective orientations were presented here in a complex ambiguity. Moreover, in the socio-cultural crisis of perestroika the traditional Baroque issues were reproduced in other historical conditions: the exhaustion of the previous model of art (now socialist realism) and the painful choice of one's path in the newly opened world space and the bitter understanding of its lag behind the dynamic development of Western culture, the desire to compensate for the lost. As in the Ukrainian Baroque of the $17^{\text {th }}$ and 18th centuries, various stages of artistic development simultaneously met in the domestic postmodern: the ideas of national revival, the intentions of not fully experienced modernism, neo-avant-garde practices, and postmodern strategies. In this complex context neo-Baroque new art renewed and intellectualized the Ukrainian tradition, through a critical rethinking of its components forced to see its meaning not only in the "positive" preservation of national values, but also as a constant source of myths and misleading illusions entrenched in culture.

Ukrainian Baroque accumulated in the works of the "new wave" a variety of its manifestations. As T. Gundorova wrote: "Baroque was perceived as almost 
Galyna Sklyarenko. "Neobaroque" in Ukrainian art in 1980s-2000s: analysis of national experience

the only aesthetically fruitful and organically self-valuable form of creativity, fully developed in Ukrainian culture. Crossing out the recent past (early $20^{\text {th }}$ century modernism and later socialist realism), being disappointed in the weakness of the national version of modernism, postmodernists turn through the heads of "parents" to the "grandfathers" - pre-modern Baroque" [10, 82], exacerbating and problematizing its content.

In the late 1980s and early 1990s the neo-Baroque style was most noticeable in the painting of the "new wave", in the style and "plots" of the paintings themselves, which were filled with biblical, legendary, fairy-tale images, and actively quoted well-known works of Western art of the $17^{\text {th }}$ and $18^{\text {th }}$ centuries; in a Baroque way interpreted the themes of national history.

Among the "Baroque" paintings of the late 1980s and early 1990s are paintings by L. Vartivanov "Untitled" (1989), "Pleiades" (1989), O. Gnilytsky "Judith and Holofernes" (1988), "Discussion of the mystery" (1988), D. Kavsan "Ave, Caesar" (1988-1989), "Gifts of the Magi" (1989), "Battle of the Yellow Waters" (1989), "Platonic love of stones" (1989), "Flight of the blue columns" (1989), "Am I Susanna?" (1990), Y. Solomka "Symmetry of the Way" (1989), V. Trubina's "Walk on the Shore" (1989), "Tsar-Fish" (1989), "Heavenly Choir, or You Can't Throw Words Out of a Song" (1989) , O. Holosij "Those Who Flee from the Thunderstorm" (1989), "Yellow Room" (1989), S. Lykov "Baroque Concert" (1987), "Bronze Reliquary" (1987), "Elegy" (1989), "Distrust of Caravaggio" (1989), "Breviary of Love” (1989), V. Raevsky's "Tsar's" and "Imperial Hunt in Russia” (1988), “Tsar's Gate” (1988), "Love over the Pink Islands" ( 1989), "Triumphal Arch" (1990), etc.

"Baroque" outlines the work of O. Roitburd - from his famous "biblical paintings" of the late 1980s - early 1990s ("The Secret Vision of Ezekiel", 1988, "The Prophet", 1988, "Whispering", 1988, "Hymn to Demons and heroes", 1989, etc.) to the great series "Roitburd vs Caravaggio" (2008-2009) and video installations "Psychedelic invasion of the battleship Potemkin into the tautological hallucination of Sergei Eisenstein" (1998) and "Eros and Thanatos of the victorious proletariat in the psycho Vertova" (2001), where various ideological and aesthetic myths - avantgarde and socialist realism - were compared in a surreal-Baroque way. These features appear in a concentrated form in the work of V. Ryabchenko. "Death of Actaeon", "Soap Characters", "Slaughterhouse" (all 1988), "Susanna and the Elders", cycle "Game with Characters", "Great Hunt" (1989), "Method of Temptation" 
(1990), "Shore of the Unmanifested characters" (1991),"Parable"(1993) and others. These works seem to illustrate the features of the Baroque, about which G. Welflin wrote: in the Baroque "appearance reigns over being"; "the real goal is to create an object-independent effect both in terms of shape and in terms of light and color"; Baroque loves intersections, (...) enjoys the new configuration that emerges from this intersection" [4, 25, 374, 370]. Releasing from the canons of Soviet art, the artists' paintings were densely filled with quotations and images from different historical epochs, author's fantasies, interpretations of well-known themes and plots and fictional "new mythology", saturating them with frank subjectivity emphasized by expressive painting.

Perhaps the most significant in this regard is the work of A. Savadov - one of the main artists of the "new Ukrainian wave", whose work has become a milestone for the domestic art of recent decades, demonstrated the indicative trends of the time. The manifesto of the new art was his (together with G. Senchenko) painting of 1987 "Cleopatra's Sorrows", which in some way synthesized the features of Ukrainian postmodernism, where neo-Baroque reflected not only figurative and stylistic features, but features of worldview and world perception. However, already in this canvas, which in an absurd way sent to the equestrian portrait of Prince Balthazar Carlos by Velazquez, depicting a chubby female figure riding a tiger in a conditional landscape, whose details were outlined by a rough line, was marked one of the most pressing problems of modern culture: reassessment of art history, liberation from stereotypes of its perception.

Baroque consciousness is characterized by a deep sense of illusory, unreal, carnival reality, which in the new postmodern era has acquired new expressiveness, where, according to the philosophers, the main principle of culture is the game between real and imagined, between "being and appear" [29, 259-260], led to a reassessment of the general system of art, its capabilities and role in culture. The new picture, according to A. Savadov and G. Senchenko, argued not only with the flat canons of socialist realism, but also with the main myth of modernism about "art as enlightenment", a truth that, as it turned out, can not prove anything and teach nothing. It is worth quoting the words of $\mathrm{K}$. Owens about the work of postmodernism, which "speaks of a desire that is constantly frustrated, of ambitions that constantly remain unfulfilled; and in this sense, his destructive blow is aimed not only at modern myths, which constitute the realm of his plots, but also at the 
Galyna Sklyarenko. "Neobaroque" in Ukrainian art in 1980s-2000s: analysis of national experience

symbolic total impulse that characterizes modern art" [18]. Perhaps, like no other in Ukrainian art, A. Savadov felt the deep drama of the search for artistic truth, which appeared for the first time in art in the Baroque era and which intensified during the new civilizational crisis of the 20th-21st centuries. Among the new challenges of civilization, art had to rebuild its space, outline its place, seek new means of expression.

...In the style of "Cleopatra's Sorrows" the artists painted several more paintings: "Welcome Season", "Melancholy", "Asylum of Babylon", where they developed free quotation of famous paintings, irony about their figurative content, parody of "great style" with its pseudopaphos and representativeness.

In 1996 (now together with O. Kharchenko) A. Savadov created a large photo panel "Innocent Invasion", with a remark "Cyber Baroque". It was a bright multifigure composition - half-naked bodybuilders in a bright entourage, as if imitating Baroque paintings. The hyper-realistic aesthetics used here, which meticulously conveyed the smallest details, programmatic spectacle and absurdity of the depicted images will become decisive in the great paintings of A. Savadov in the 2000s ("Heart", 2006; "Whirligig", 2007; "Fio-land", 2009; "Hommage of Maria Pryimachenko", 2010; "Laboratory of Orpheus", 2012, etc.). A. Savadov's great panels seem to parody the main principles of the Baroque work: external pathos, decorativeness, bizarre ambiguity, inseparability of truth and fiction, internal tension hidden behind irony and grotesque. It is worth quoting a well-known characteristic of the Baroque, given by M. Foucault: "These are games whose charm is enhanced by the similarity of resemblance and illusions; chimeras of likeness appear everywhere, but it is known that they are only chimeras; it is a special time of props, comic illusions, theater (...), it is a time of deceptive feelings; it is a time when metaphors, comparisons and allegories define the poetic space of language" [30, 100]. In A. Savadov's paintings these features are programmatically accentuated, as if bringing the Baroque model of the work to its exhaustion.

However, at the same time, in the 1990s, the artist created photo projects in which Baroque articulates now purely social problems related to the dramatic collisions of life in modern Ukraine. Among them - "Deepinsider" (1998, with the participation of $\mathrm{O}$ Kharchenko), which, as always by this artist, combined the incompatible - tragedy and farce, reality and outright theatricality, harsh truth and fiction. The author turned here to extreme situations, which give the opportunity 
to sharpen the topic, to present it in a new perspective, to provoke a direct reaction from the viewer. As, for example, in "Fashion at the cemetery", where models in candid outfits posed against the background of graves and funeral processions. Perhaps one of the first in Ukrainian art, the artist turned here to one of the most pressing issues of our time: reality and show business, which transforms any life event through the prism of "beauty and gloss".

... Since its inception, the series "Donbass-Chocolate" has been repeatedly exhibited at domestic and international exhibitions, entered the milestones of world art of the late 19th and early 20th centuries [24, 200-201]. This work not only debunked the main Soviet myth "about the man of labor" as the master of the country, but also addressed the most pressing problem of the time: the decline of the mining industry and more broadly - manual labor, which in economic and political crisis in society most severely affected its workers life: since the early 1990s, protests by miners in Ukraine have become a manifestation of the deep social tensions. The artist turned here to candidly staged photos, turning the miners into bodybuilders who become participants in an absurdist performance. But the miners trusted the artist: they were photographed naked, in snow-white ballet tutus, in shiny masks... The filming took place in real Ukrainian mines, sometimes life-threatening, near the scorching heat. According to the Baroque principle of contrast the photo series by A. Savadov demonstrated the almost classical beauty of men's bodies and terrible working conditions, combining them with "ballet", which ruled as a metaphor for the "official culture" that covered the anti-human everyday life since Soviet times. However, the meaning of "ballet" seen by the artist is not unambiguous: this refined art of classical dance is known to be based on constant exhausting work, and its world is no less cruel than the work of a miner, light movements of dancers hide blood and sweat... The theme raised by the artist remains relevant. The drama of Ukrainian miners emerged with new force in 2014, concentrating around itself the most painful problems of today.

In 1999 A. Savadov shot the photo series "Collective Red". The appeal to the Soviet past, which is increasingly overshadowed by new myths in the public consciousness, is considered by the artist in a wide space of art and culture, where "red" - the color of the Soviet flag, is not limited to marking ideology and propaganda, but also has another meaning - passion, life, death and painting 
Galyna Sklyarenko. "Neobaroque" in Ukrainian art in 1980s-2000s: analysis of national experience

itself. It is no coincidence that the scenes of political demonstrations with red flags coexist in the "Collective Red" with scenes in slaughterhouse and bullfighting characters, attaching the motif of sacrifice and violence to the figurative space. The skinned carcasses of animals in A. Savadov's photographs evoke the paintings of H. Sutin, the myth of the Minotaur, and the still lifes of the artists of the 17th 18th centuries. The artist's performances recorded in the photo are emphatically theatrical, and their spectacle, as in the Baroque, is mixed with tragedy; and the figurative pathos is almost classical. However, his sociality is not only critical but also philosophical. Presented in the exhibition "Myth "Ukrainian Baroque" along with the burning colors of folk painting, intense colors of the Ukrainian avantgarde and the tragic-romantic canvas of V. Palmov "For the Power of the Soviets!" (1927), the series "Collective Red" seems to unite different epochs in Ukraine, illustrating the cruel "theater of history", the price of artistic expression of which is human life. "In my opinion," the artist thinks, "the artist should not be simply social. He paints people because he himself is a participant in a joint dialogue. Instead, the artist's task is to experience and glorify the divine beauty, and not to literally brand the flaws of a society that will always be underdeveloped. Personal salvation, same as death, is the work of each individual" [20].

A. Savadov's photo series "Book of the Dead" (2001) became perhaps the most shocking work of the artist. And although the theme of death in one way or another outlines the entire history of world art, at at various times interpreted either epic and sublime or harshly naturalistic, in this case its interpretation struck by the unexpectedness of the author's approach. After all, for his work he used real human corpses, which were taken from the morgue and compiled into certain "plots". Terrifying scenes resembled fragments of horror films or the Baroque paintings with a weave of human bodies... However, A. Savadov's "Book of the Dead" had a very relevant social meaning, drawing attention to the "cultural necrophilia" that infects the whole modern Ukrainian culture, where for the sake of uniting the nation politicians in one way or another openly manipulate national tragedies, using in their PR technologies victims of the Holodomor, World War II, and now those killed on the Maidan, and the constant topic of discussion in society remain unsolved murders. Composing his terrible "scenes", the artist raises questions about the value of human life, about the known and unknown deceased and perished, which the government uses for its political purposes. 
"The world of the dead is a reflection of the world of the living," says the artist. "But we try not to notice it..." [25]

Researchers note that in many post-Soviet states, including Ukraine, interest in the past often revolves around "abuse of history," mostly represented by myths, symbols, saints, heroes, and martyrs who emerge from their graves when summoned. History serves as a reservoir for the reproduction of the national spirit, an instance for substantiating the vital right of the nation, for legitimizing the threat of violence. Complexes of threat and demonstration of strength, fear and readiness for aggression are brought together. (...) National sentiment is forged and directed against a neighbor with a foreign religion and language, who must be held accountable for the injustice done to the nation - no matter if it was recently or many centuries ago" $[7,30]$. It is the new art that has become in Ukraine the space of cultural reflection, where the artistic analysis of the ambiguity of historical issues is reflected.

In this regard, the relevance of Baroque visions in Ukraine is most examplary illustrated by a kind of "historical mystification" that took place on May 19, 1990 in the Kyiv Teachers' House, where the young poet V. Tsibulko read a text entitled "Transnational hit or gold of Pavlo Polubotko." The outspoken postmodern simulacrum suddenly fell on fertile ground. About the "gold of Hetman Polubotko", which since the 18th century was allegedly kept in the Bank of London, in one week spoke all of Ukraine including the Verkhovna Rada. There were also those who estimated that now, together with interest, this account accounts for 50,000 pounds per Ukrainian, with which the country can easily solve all its economic problems. Later V. Tsibulko said: "It was a kind of artistic provocation and no one knew how it would end, but it turned out that it had to be thrown into the mass consciousness just then" [17]. In the public perception of this action, in the discussions around it, the paradoxes of "historical time" in Ukraine were reflected, which exists here in a kind of "Future in the Past". Therefore, despite the declared "European choice" of national development with its primarily progressive vector, "Ukrainian time" remains mythological, freely transformed, because of which the "past" does not end and is often appealed to in solving problems of the future.

It is no coincidence that "historical time" and "national values" became the theme of one of the milestones for contemporary art of Ukraine art projects 
Galyna Sklyarenko. "Neobaroque" in Ukrainian art in 1980s-2000s: analysis of national experience

"Ukrainian Money" by O. Tistol, consisting of drawings, etchings, large paintings and large-scale installations. Started in 1984, at the end of the Soviet era, according to the mythology of which money was to disappear in the new communist society, it passed into the present - capitalist reality, when money became the defining lever of life (in the mid-1990s M. Matsenko joined the project). In the interpretation of the artists, money appears as a cultural and symbolic category, which not only captures the history of national statehood (as we know, in 1918 the design of "Ukrainian karbovanets" was developed by such prominent artists as G. Narbut, M. Boychuk, O. Bogomazov), but also reflects the main problem of Ukraine - the choice of values, real and deceptive. Combining in their project historical "Ukrainian brands" - the legendary Roxolana (Ukrainian captive who became the wife of the Turkish sultan), hetmans, Cossacks on horseback, read through the Soviet aesthetics of stencils and clichés pseudo-Baroque ornaments, the authors involve the characters of national mythology in the "marked space" of the modern market, while drawing attention to the current topic of "utopias and exchanges", ideologies that become market values, and art itself, which exists today at the intersection of cultural processes and marketing strategies, where a combination of artistic trends, market laws and social processes determines the significance and price of a work of art. It is no coincidence that B. Groys considers identity itself as a market, capitalist concept, it "functions because a business with a certain name functions, it functions de facto as long as there is the factuality of certain things" $[8,111]$. In the Ukrainian context, this issue becomes particularly acute, reflecting the transition from the illusion of ideologies to the creation of a real material and cultural "product", the quality, content and impact of which should ultimately determine "Ukrainian values".

The theme of "manipulation of history" was later continued by the project of O. Tistol and M. Matsenko "Mother of Cities" (2005) with color photos of the facades of famous Kyiv buildings: the National Art Museum of Ukraine, Taras Shevchenko University, Mariinsky Palace, etc. "Cleansed" of the surrounding buildings, the architectural facades appear here as part of a large historical "theater", a monumental "scenography", capable of staging any changes in the social context...

However, the "Baroque theme" in the artist's work began earlier - in the group "Volitional facet of national post-eclecticism" created by him together with 
K. Reunov, M. Skugareva, J. Bystrova and O. Kharchenko in 1989. As O. Sviblova wrote in 1990: Baroque is "a style that has not fully exhausted its possibilities, contains enormous transformational potentials, which are brilliantly used by young Ukrainian artists. Addressing the "crazy" colors of Ukrainian parsuns, involving specific South Russian literature in the works, that is, excessive, albeit burdensome, metaphoricalness, "Will Edge" seems to emphatically demonstrate its national roots. At the same time, pretending to be nationalists, they still profane this type of consciousness... If there is a game with history - it is confusing and profane, but at the same time the dignity of a high subject is preserved" [21, 40]. In O. Tistol's paintings "Farewell of the Slavic woman" (1987), "Reunification" (1988), “Them” (1988), "Suvorov" (1992), "Exercises with maces” (1989), "Zinovy Bogdan Khmelnytsky" (1990) etc., ironically, with a sense of humor and hidden personal involvement, the world of Ukrainian Baroque was recreated, with its scope and pathos, grotesque quasi-academicism and folklore naivety, a mixture of sublime and low, beautiful and ugly. And the details of the paintings mixed the attributes of the Ukrainian Baroque (maces of Ukrainian hetmans, emblems, elements of ornaments, etc.) and Soviet symbols, techniques of complex "high" painting and "monumental propaganda". The sharpened neo-Baroque style is also noted in K. Reunov's paintings "On the Slopes of the Dnieper" (1988), "Winners are not judged. A gift to the great Russian people from the great Ukrainian people" (1989),"Cutlet in Kyiv style” (1989), "Don't say no" (1989),"In search for a happy ending" (1990) etc., which paradoxically combined the inherent to the historical Baroque "gaps between form and content" (S. Zizhek), "nationalization of imported artistic principles" and "folklorization of their ideas" (Y. Lotman) with eclecticism and falsity of Soviet aesthetics, and included in the painting words, letters, phrases destroyed the usual picture format, emphasizing their belonging to another - the conceptual era. The Baroque paintings of O. Tistol and K. Reunov reflected the transitional period of the late 1980s - early 1990s, with its mobility, uncertainty, the end of the old Soviet and the beginning of a new - then still unknown era. As O. Sviblova wrote: "Oleg Tistol and Konstantin Reunov create a beautiful, even luxurious world. Sometimes its exaggerated beauty is alarming. Elements of rot and decay begin to appear in the perfect Tistol palette. Brilliant Baroque compositions by Konstantin Reunov fall off like soap suds. The motif of finality is woven into almost all the works of young Ukrainian artists..." [21, 40-42] 
Galyna Sklyarenko. "Neobaroque" in Ukrainian art in 1980s-2000s: analysis of national experience

Close to them were the paintings of the group member M. Skugareva ("Portrait of a young man", 1991; "Portrait of Oleg Tistol”, 1990; “Tistol”, 1992; "Sevastopol Waltz", 1994; Fragment, 1995; "Partagas", 1997), in which human figures and decorative elements are complexly intertwined, as if trying to cover the internal crisis with "beauty". The artist's paintings combine irony about the classic "nude", a certain "gesture" in the direction of Soviet monumental art (ceramic tile motif) with interspersed in the painting embroidered fragments - a bird, a face, a flower... Their "Baroque origin" is evidenced by the location itself - in the upper corner of the canvas, where ancient portraits traditionally depicted heraldic compositions. In the combination of distinctly picturesque naked figures, ornamental background and volume of the embroidered fragment, a special structure of the Baroque picture unfolds - at the same time a means of representation and an element of space decoration.

In the mid-1990s, O. Tistol and M. Matsenko formed the "Natsprom" group, continuing the study of the "beauty of national stereotypes" begun by the "Will Edge". Their joint works (in addition to the named - panels "Pilsudski" (1993), projects "Museum of Architecture" (1996), "Museum of Ataturk" (1995), etc.), became a form of study of paradoxes of national history, features of national worldview with their inherent admiration for beauty and a tendency to myth-making.

Since the early 2000s, M. Matsenko has been working on a large "Heraldic cycle", where, according to the tradition begun in the Baroque era, he visualizes the symbols, slogans and ideas of the Soviet era ("Gifts of fields", "Beautiful and useful", "There will be bread - there will be a song", "Art belongs to the people", "Happiness in work", etc.), or invents logos of fantastic institutions, such as "Ukryakirlantskanatprom"... In his ornamental and symbolic compositions, the artist seems to illustrate the closeness of aesthetic stereotypes preserved in Ukrainian culture. After all, just like in the ornaments of Kyivan Rus, lines curl in the Baroque graphics, in intricate fonts of Ukrainian modernism, in folklore drawings, in Soviet posters, reviving in graffiti on the streets of modern Ukrainian cities. In M. Matsenko's "heraldry" coexist hetman's maces, shovels and scythes, hammers, corn, mobile phones, potatoes, guitars, pitchforks, lush roses, chains, ears..., which he turns into symbols and signs of culture, for which the choice of values, national, household, aesthetic still remains almost the main problem. 
The works of S. Panich demonstrate a peculiar vision of Baroque traditions. Unlike most of the artists of the "new wave", who were attracted to Baroque primarily by the free painting, he turned to Baroque graphics, with its lush ornaments and intricate allegory. The artist's paintings of 1990 - "The Apotheosis of Painting", "Take the Word of Consolation", "I Love You All Very", "Vine for Widows and Spouses" - are similar to large (300 x 200) painted engravings of Baroque eulogies. It is noteworthy that the first in this series of works by the artist was a large series of paintings "Swan Lake", which was created during the collapse of the USSR 1990-1992, despite the lack of signs of time and outright socio-political allusions. It is worth recalling that the well-known ballet "Swan Lake" to the music of P. Tchaikovsky in the late Soviet years became a kind of "sign of trouble" of the state system, which was about to disappear: the ballet was shown on television and broadcast along with other classical musical works on the radio during crisis situations - the death of the next head of the state, a political uprising, etc. Seeing a scene "with white swans" on the screen, the citizen of the USSR immediately understood: something had happened in the country. Ballet was used as a political setting, and therefore as part of the popular culture. Meanwhile, Baroque graphics for its time was also perhaps the most democratic art form, spread along with the print media. Ascetic in color (white, black, a little red) paintings by S. Panich depicted stylized flowers and hypertrophied human figures in complex tense poses, there were texts - fragments from poems of the early 20th century, which parodied or reinforced the pseudo-plot motif, where tragic, lyrical, ironic intertwined in a tight figurative knot. Quite on Baroque principles, the artist seemed to confuse the viewer with reminiscences, allusions, historical analogies...

The collapse of the USSR and new geopolitical issues of the end of the $20^{\text {th }}$ - beginning of the $21^{\text {st }}$ century were reflected in their own way in the works of Y. Solomko: in 1991 he began his great art project "Art Cartography", where the basis for his works were geographical maps of individual countries and the world, on which he "imposes" quotes from famous paintings or his own compositions. The first of them were works of the early 1990s: "Morning Toilet", "Gallant Couple", "Kiss Stealthily", "Pleasant Evening", "Concert", etc., in which the "material" for the artist's creative experiment were paintings by artists of the era Baroque and rococo. Whimsical pastures of the most "artificial", theatrical styles of art easily fit into the tortuous outlines of continents, islands 
Galyna Sklyarenko. "Neobaroque" in Ukrainian art in 1980s-2000s: analysis of national experience

and countries, as if visualizing the idea of mobility and relativity of any fixation of reality, where changes in state borders on maps reflect the uncertainty of life and traditional values. Later, Y. Solomko noted: "The map has become a symbol of the modern world for me. I now take any political events on the planet very personally (...). After all, the map of the world for me from the beginning is also a background for the interpretation of art history, an impetus for an exciting postmodernist journey" $[22,13]$. Among the work of the artist, which in its own way reproduces purely Ukrainian issues, "The Last Barricade" (2003), where against the background of the map of the Crimea, two figures are fighting among themselves; or "Ukraine" (2009) with a mysterious closed female figure along the map of Ukraine, which seems to hint at a still unknown, hidden national history; or a work with one of the most common Baroque images - "Labyrinth" (2010), which covers the map of Ukraine, metaphorically illustrating the complex search for a choice of ways of development of the state...

Considering the peculiarities of the interpretation of the Baroque experience in contemporary Ukrainian art, it is impossible to miss the most controversial film "Prayer for Hetman Mazepa" (2001, directed by Yuri Ilyenko), which due to active participation of the S. Yakutovych in its creation was called by critics "Painted movie". Apparently, here the Ukrainian national problems that have accumulated in the cultural consciousness over the centuries have been visualized perhaps most clearly and ambiguously. Built without a consistent account of events, shocking, designed to provoke an emotional reaction, to provoke painful reflections on the dramatic problems of Ukrainian life, the film became in tune with the general imagery and artistic intentions of postmodern neo-Baroque, which are characterized by "theater" (J. Balandier), "vacuum era" (J. Lipovetsky), "system of simulacra" (J. Baudrillard). Ilyenko consciously builds the frame, scenery, entourage, costumes of the characters in this way," said Y. Shevchuk, "in order to deprive the viewer of the slightest opportunity to believe in the historicity of the moment. (...) It seems that Ilyenko set himself the task of deconstructing, destroying the usual myths, cults, which have become mandatory for Ukrainians in their approach to prominent historical figures" $[32,74]$. For the film S. Yakutovych created large multi-figure canvases, installations of real and artificial objects, spatial architectural structures, stylized in the spirit of Baroque buildings. Design elements were not only part of the composition of the frames, but also were important 
parts of the action. In the Ukraine, shown in the film, only nature, a landscape with fields and rivers, remained real, yet everything else appeared as props, mock-ups, into which the characters turned. Quite in a postmodern way, the authors of the film built a provocative optics of the vision of the history, revealing the contradictions between fictional and real, legendary and real, filling the old plots with relevant allusions. There is no coincidence that one of the culminating moments of the tape was, though full of exaggerated pathos, Mazepa's exclamation: "To be a ruin or to be Ukraine?"...

At one time G. Welflin emphasized: "Baroque or lets say, modern art is not a decline, not an improvement of classical art, it is - in general - another art" $[4,22]$. It opened a new era that challenged classical idealization and canonicity, emphasizing a new dynamic, moving, antinomic perception pierced with drama and a sense of instability. In the new conditions of civilization of the late $20^{\text {th }}-$ early $21^{\text {st }}$ century these features were reproduced anew, actualized by sociopolitical, economic, ideological crises that humanity is experiencing. The difficult formation of Ukrainian independence seemed to synthesize this issue, filling it with its own national historical experience. New art, which entered the art scene from the years of perestroika, in its own, now postmodern, way rethought and analyzed the national traditions. Their works reflected both the critique of culture and society, and the ambiguous artistic reaction to the events, and the desire to retell, reproduce, convey the controversial content of the Ukrainian experience. The neo-Baroque reflected important features of national consciousness, at a new stage of cultural development articulating its cross-cutting problems and meanings.

\section{REFERENCES}

1. Apologhija. Manifesty. Deklaraciji. Monologhy [Apology. Manifestos. Declarations. Monologues] (1996) Kyjiv : Kur'jer muz. (in Ukrainian).

2. Beseda s izobretatelem transavangarda (1992) : intervyu V. Miziano s A. Bonito Oliva [Conversation with the inventor of the transavant-garde. V. Misiano's interview with A. Bonito Oliva]. Iskusstvo, no. 1, pp. 23-25. (in Russian).

3. Velflin G. (1913) Renessans i barokko [Renaissance and Baroque]. SanktPeterburg: Gryadushchiy den. (in Russian). 
Galyna Sklyarenko. "Neobaroque" in Ukrainian art in 1980s-2000s: analysis of national experience

4. Velflin G. (1994) Osnovnye ponyatiya istorii iskusstv. Problema evolyutsii stilya $\mathrm{v}$ novom iskusstve [Basic concepts of art history. The problem of style evolution in new art]. Sankt-Peterburg : Mifril. (in Russian).

5. Ghobsbaum E. \& Rejndzhere T. (ed.) Vynajdennja tradyciji [Invention of tradition] / red. E. Ghobsbaum ta T. Rejndzhere. Kyjiv : Nika-Centr. (in Ukrainian).

6. Vid baroko do Baroko. Khudozhnjo-literaturna akcija, prysvjachena barokovij kuljturi XVII-XVIII stolitj i neobarokovym techijam XX stolittja [From baroque to baroque. Artistic and literary action dedicated to the baroque culture of 17th-18th century and neo-baroque currents of the 20th century] : tezy dopovidej (1996). Kyjiv : NkhMU. (in Ukrainian).

7. Gayer D. (1995) Nasilie i istoriya v postkommunisticheskoe vremya [Violence and history in post-communist times]. Voprosy filosofii, no. 5, pp. 30-31. (in Russian).

8. Groys B., Ryklin M. (2002) Rynok vmesto Arkhiva [Market instead of Archive]. Iskusstvo kino, no. 2, pp. 104-115. (in Russian).

9. Ghrushevsjkyj M. (2001) Po shkodi [On Damage]. Pam'jatj stolitj, no. 5, pp. 13-14. (in Ukrainian).

10. Ghundorova T. (2005) Pisljachornobyljsjka biblioteka. Ukrajinsjkyj literaturnyj postmodern [Post-Chernobyl library. Ukrainian literary postmodern]. Kyjiv : Krytyka. (in Ukrainian).

11. D'Ors E. (2006) Barokko - istoricheskaya konstanta [Baroque as a historical constant]. Filosofskie nauki, no. 1, pp. 59-68. (in Russian).

12. Skljarenko Gh. \& Barshynova O. (ed.) (2012) Mif "ukrajinsjke baroko" [Exhibition catalog "Myth "Ukrainian Baroque"] : kat. vyst. 27.0426.08.2012, Kyjiv / avt. Gh. Skljarenko, O. Barshynova. Kyjiv : NkhMU. (in Ukrainian).

13. Konrad N. I. (1974) Izbrannye trudy. Istoriya [Selected works. History]. Moskva : Nauka. (in Russian).

14. Krymsjkyj S. (2004) Mentalitet ukrajinsjkogho barokko [Ukrainian Baroque mentality]. Ukrajinsjke baroko. Kyjiv: AKTA, vol. 1, pp. 21-48. (in Ukrainian).

15. Lukomskiy G. (2011) Ukrainskiy barokko [Ukrainian Baroque]. Apollon, no. 2, pp. 5-13. (in Russian).

16. Makarov A. (1994) Svitlo ukrajinsjkogho baroko [Light of the Ukrainian Baroque]. Kyjiv : Mystectvo. (in Ukrainian). 
17. Onysjko O. (2000) Lycari rozmytogho imidzhu [Knights of blurred image]. PIK (Polityka i Kuljtura), no. 13 (48), pp. 36. (in Ukrainian).

18. Ouens K. Allegoricheskiy impuls: $\mathrm{k}$ teorii postmoderna [Allegorical impulse: towards postmodern theory]. Available at: https://spectate.ru > allegorical2-1 (accessed 2 August 2021). (in Russian).

19. Parakhonsjkyj B. (1993) Barokko. Poetyka i symvolika [Baroque. Poetics and Symbolism]. Filosofsjka $i$ sociologhichna dumka, no. 6, pp. 99-114. (in Ukrainian).

20. Savadov A. (2009) S molodezhyu obshchayus neposredstvenno ... [I communicate with young people directly...]. Ukrajinsjka pravda, 28 veresnja. Available at: https://life.pravda.com.ua > socie. (accessed 11 July 2021).

21. Sviblova O. (1990) V poiskakh schastlivogo kontsa [Looking for a happy ending]. Rodnik, no. 5, pp. 37-43. (in Russian).

22. Solomko Ju. Postmodernistsjkyj vojazh [Postmodern voyage]. Apologhija. Manifesty. Deklaraciji. Monologhy. Kyjiv : Kur'jer muz, pp. 13. (in Ukrainian).

23. Stetsenko Ye. A. (2002) Kontseptsiya traditsii v literature XX veka [The concept of tradition in the literature of the 20th century]. Khudozhestvennye orientiry zarubezhnoy literatury XX veka [Artistic landmarks of foreign literature of the 20th century] / pod red. A. B. Bazilevskogo. Moskva : IMLI RAN, pp. 47-83. (in Russian).

24. Teylor B. (2006) Aktualnoe iskusstvo. 1970-2005 [Contemporary art. 19702005]. Moskva : Slovo/Slovo. (in Russian).

25. Tkachuk T. (2003) Samyy skandalnyy ukrainskiy khudozhnik Arsen Savadov [The most controversial Ukrainian artist Arsen Savadov]. Fakty, 5 sentyabrya. (in Russian).

26. Ukrajinsjke baroko : v 2 t. [Ukrainian Baroque : in 2 vol.]. (2004) Kyjiv : AKTA. (in Ukrainian).

27. Ushkalov L. (2011) Vid baroko do postmodernu : eseji [From Baroque to postmodern : essays]. Kyjiv : Ghrani-T. (in Ukrainian).

28. Fedotov G. P. (1989) Tri stolitsy [Three capitals]. Novyy mir, no. 4, pp. 218-239. (in Russian).

29. Podoprigora S. Ya. \& Podoprigora A. S. (ed.) (2013). Filosofskiy slovar [Philosophical dictionary] / avt.-sost. S. Ya. Podoprigora, A. S. Podoprigora. Rostov-na-Donu : Feniks. (in Russian). 
Galyna Sklyarenko. "Neobaroque" in Ukrainian art in 1980s-2000s: analysis of national experience

30. Fuko M. (1977) Slova i veshchi. Arkheologiya gumanitarnykh nauk [Words and things. Archeology of the humanities]. Moskva : Progress. (in Russian).

31. Chepelyk V. (2004) Arkhitektura ukrajinsjkogho neobaroko [Architecture of the Ukrainian Neo-baroque]. Ukrajinsjke baroko [Ukrainian Baroque] : in 2 vol. Vol. 2. Kyjiv : AKTA, pp. 269-368. (in Ukrainian).

32. Shevchuk Ju. (2005) "Molytva za ghetjmana Mazepu" u Gharvardi ["Prayer for Hetman Mazepa" at Harvard]. Kinoteatr, no. 1, pp. 59-61. (in Ukrainian).

33. Jauss Gh. R. (1996) Estetychnyj dosvid i literaturna ghermenevtyka [Aesthetic experience and literary hermeneutics]. Antologhija svitovoji literaturnokrytychnoji dumky XX stolittja [Anthology of world literary and critical thought of the 20th century] / za red. M. Zubycjkoji. Ljviv : Litopys, pp. 278-307. (in Ukrainian). 